\title{
Microvirga Jeongseonensis Sp. Nov., New Species Isolated From Soil in South Korea
}

\section{Soohyun Maeng}

Seoul Women's University

\section{Yuna Park}

Seoul Women's University

\section{Hyejin Oh}

Seoul Women's University

\section{Minji Bang}

Seoul Women's University

Jigden Baigalmaa

Mongolian National University of Medical Sciences S. Zorig street-3

Jaewoo Bai

Seoul Women's University

Myung Kyum Kim ( $\boldsymbol{D}$ biotech@swu.ac.kr)

Seoul Women's University https://orcid.org/0000-0003-4098-1520

\section{Research Article}

Keywords: Methylobacteriaceae, Microvirga, novel species, Taxonomy

Posted Date: May 11th, 2021

DOI: https://doi.org/10.21203/rs.3.rs-483226/v1

License: (c) (i) This work is licensed under a Creative Commons Attribution 4.0 International License.

Read Full License 


\section{Abstract}

A novel Gram-stain-negative, aerobic, rod-shaped, convex, and light pink-colored strain $B T 688^{\top}$ was isolated from a soil sample collected in Jeongseon city, South Korea. Phylogenetic analysis based on 16S rRNA gene sequence revealed that strain $\mathrm{BT}^{\mathrm{S}} 688^{\top}$ belongs to a distinct lineage within the genus Microvirga (family Methylobacteriaceae, order Rhizobiales, class Alpha Proteobacteria, phylum Proteobacteria). The $16 \mathrm{~S}$ rRNA gene sequence similarity between strain $\mathrm{BT}^{2} 688^{\top}$ and Microvirga aerilata $5420 \mathrm{~S}-16^{\top}$ was $98.5 \%$. Strain $\mathrm{BT} 688^{\top}$ had Q-10 as a major respiratory quinone and the major polar lipids of strain $\mathrm{BT} 688^{\top}$ was diphosphatidilglycerol (DPG), phosphatidylglycerol (PG), phosphatidylethanolamine (PE), and phosphatidylcholine (PC). The major cellular fatty acids of strain BT688 ${ }^{\top}$ were $\mathrm{C}_{18: 1} \omega 7 c(76.0 \%)$ and summed feature $3(9.6 \%)$.

Based on the polyphasic characteristics, strain $\mathrm{BT} 688^{\top}$ can be suggested as a novel bacterial species within the genus Microvirga and the proposed name is Microvirga jeongseonensis. The type strain of Microvirga jeongseonensis is $\mathrm{BT}^{2} 688^{\top}\left(=\mathrm{KCTC} \mathrm{XXXX}^{\top}=\mathrm{NBRC}_{114857^{\top}}\right)$.

\section{Introduction}

The genus Microvirga was first described by Kanso and Patel (2003) belonged to the family Methylobacteriaceae order Rhizobiales. At the time of writing (April 2021), the genus comprises 18 validly published species (http://www.bacterio.net/Microvirga.html). Microvirga species have been retrieved from various polar environments including regoliths, Tibet hot spring sediments (Liu et al. 2020), roots of rapeseed plants (Jimenez-Gomez et al. 2019), root nodule (Wang et al. 2019), forest soil (Zhang et al. 2019), rhizospheric soil (Li et al. 2020) and root nodule (Msaddak et al. 2020), respectively. In genus Microvirgaare, cells are Gram strain-negative, the average genome size is 3.53-9.63 Mb, and DNA G + C contents were $61.1-65.1 \%$ (Zhang et al. 2019). They contain $\mathrm{C}_{18: 1} \omega 7 c$ and cyclo- $\mathrm{C}_{19: 0} \omega 8 c$ as major fatty acids.

In this study, strain $\mathrm{BT} 688^{\top}$ was newly isolated from a soil sample collected in Jeongseon city, South Korea, and characterized. Phylogenetic analysis, phenotypic, genotypic, and chemotaxonomic characterization were performed to determine the taxonomic position of strain $\mathrm{BT}^{\mathrm{C}} 688^{\top}$. The results suggest that strain $\mathrm{BT} 688^{\top}$ represents a novel species of the genus Microvirga, for which the name Microvirga jeongseonensis sp. nov. is proposed.

\section{Materials And Methods}

\section{Bacteria isolation and culture conditions}

Strain BT688 ${ }^{\top}$ was isolated from Jeongseon city ( $\left.37^{\circ} 22^{\prime} 38.1^{\prime \prime} \mathrm{N}, 128^{\circ} 47^{\prime} 17.0^{\prime \prime} \mathrm{E}\right)$ located in South Korea. A single colony was isolated using Reasoner's 2A (R2A) agar medium (Difco) after incubation at 
$25^{\circ} \mathrm{C}$ for 10 days. Then the strain was routinely cultured on R2A agar at $25^{\circ} \mathrm{C}$, maintained at $4^{\circ} \mathrm{C}$, and stored in $20 \%(\mathrm{w} / \mathrm{v})$ glycerol suspension at $-80^{\circ} \mathrm{C}$, respectively.

\section{Morphology, physiology, and biochemical analysis}

The cell morphology of strain $\mathrm{BT} 688^{\top}$ was examined using transmission electron microscopy (JEOL, JEM1010, Japan) by negative staining method. The Gram staining was performed using a kit follow the manufacturer's instruction (bioMérieux, France). Catalase activity was examined with $3 \%(w / v) \mathrm{H}_{2} \mathrm{O}_{2}$ solution and oxidase activity was examined by adding $1 \%(\mathrm{w} / \mathrm{v})$ tetramethyl-p-phenylenediamine (Cappuccino and Sherman 2002). The growth of strain BT688 ${ }^{\top}$ was examined on R2A agar, Luria-Bertani (LB) agar, Tryptic Soy Agar (TSA), Nutrient Agar (NA), and on MacConkey agar, respectively. In addition, growth was determined at different temperatures $\left(4,10,15,25\right.$ and $\left.30^{\circ} \mathrm{C}\right)$, under various $\mathrm{pH}$ conditions $(5$ to $9,1 \mathrm{pH}$ intervals), and with different $\mathrm{NaCl}$ concentrations (1-5\% [w/v \%], $1 \%$ intervals), respectively. API 20NE and API ZYM tests were performed according to the manufacturer's instruction (bioMérieux, France).

\section{Phylogenetic analysis}

The $16 \mathrm{~S}$ rRNA gene of strain $\mathrm{BT} 688^{\top}$ was amplified using two universal bacterial primers $27 \mathrm{~F}$ and $1492 \mathrm{R}$ (Weisburg et al. 1991). The 16S rRNA gene sequence was identified using the EzBioCloud server (https://www.ezbiocloud.net/). The sequence was analyzed using the 337F, 518R, 785F and 926R universal primers (Macrogen, Korea). To determine the taxonomic position of strain $\mathrm{BT}^{\mathrm{T}} 688^{\top}, 16 \mathrm{~S} \mathrm{rRNA}^{\mathrm{T}}$ sequences of closely related species were obtained from EzBioCloud (Yoon et al. 2017) and compared with that of strain $\mathrm{BT} 688^{\top}$ using EzEditor2 program. Phylogenetic trees were reconstructed using the MEGAX program (Kumar et al. 2018) with the neighbor-joining (Saitou and Nei 1987), maximumlikelihood (Felsenstein 1981), and maximum-parsimony algorithms (Fitch 1971). The stability of the tree topologies was evaluated by bootstrap analysis based on the 1,000 resampling method (Felsenstein 1985). Evolutionary distances were calculated according to the Kimura two-parameter model (Kimura 1983).

\section{Whole-genome sequence analysis}

The genomic DNA of strain $\mathrm{BT} 688^{\top}$ was extracted using a genomic DNA extraction kit according to the manufacturer's instruction (Solgent, Korea). The sequencing libraries were prepared using the Nextera DNA Flex Library Prep Kit (Illumina) and whole-genome sequencing was performed using iSeq 100 . The partial genome sequences were assembled by using the SPAdes algorism (ver. 3.10.1, Algorithmic Biology Lab, St. Petersburg Academic University of the Russian Academy of Sciences). The wholegenome sequence of strain $\mathrm{BT} 688^{\top}$ was deposited in GenBank (www.ncbi.nlm.nih.gov/) database. The genome sequence of strain $\mathrm{BT} 68^{\top}$ was annotated by the National Center for Biotechnology Information Prokaryotic Genome Annotation Pipeline (PGAP) (Tatusova et al. 2016). The average nucleotide identity (ANI) was calculated using EzBioCloud (https://www.ezbiocloud.net) and the digital DNA-DNA 
hybridization (dDDH) value was calculated using the Genome-to Genome Distance Calculator (GGDC) with the recommended formula 2 (Meier-Kolthoff et al. 2013).

\section{Chemotaxonomic characteristics}

To analyze the composition of cellular fatty acid, polar lipid, and quinone strain $\mathrm{BT} 688^{\top}$ was grown on R2A agar at $25^{\circ} \mathrm{C}$ for 3 days and collected cells were freeze-dried. Polar lipids of strain $\mathrm{BT}^{\mathrm{T}} 688^{\mathrm{T}}$ were extracted as described by Minnikin et al. (1984). The total lipids, glycolipids, phosphatidylcholine, and amino lipid groups were separated using two-dimensional thin-layer chromatography (TLC) and detected by using proper detection reagents (Komagata and Suzuki 1987). Fatty acids were purified by saponification, methylation, and extraction procedures (Sasser 1990). Lipoquinones were extracted using the Sep-Pak Vac cartridges (Waters) and analyzed by high-performance lipid chromatography (HPLC) based on previous methods (Hiraishi et al. 1996). The fatty acid methyl esters (FAME) were identified using the Sherlock Microbial Identification System V6.01 (MIS, database TSBA6, MIDI Inc).

\section{Results And Discussion}

\section{Morphology, Physiology and Biochemical analysis}

Strain BT688 ${ }^{\top}$ was Gram-negative and had rod-shaped morphology (Fig. S1). Colonies of strain BT688 ${ }^{\top}$ were circular, convex, smooth, and light pink color after incubation for three days at $25^{\circ} \mathrm{C}$. Cells of strain $\mathrm{BT} 688^{\top}$ could grow at 10 to $30^{\circ} \mathrm{C}$ (optimum $25^{\circ} \mathrm{C}$ ) and $\mathrm{pH} 6.0-9.0$ (optimum 7.0) on R2A agar. Different features between the newly isolated strain and reference strains were provided in Table 1 . The negative reactions of strain $\mathrm{BT} 688^{\top}$ on API kits were shown in the supplementary table (Table S1).

\section{Phylogenetic and genome sequence analysis}

The length of the $16 \mathrm{~S}$ rRNA gene of strain $\mathrm{BT} 688^{\top}$ was $1,428 \mathrm{bp}$. Based on the $16 \mathrm{~S}$ rRNA gene sequence similarities, strain $\mathrm{BT} 688^{\top}$ was affiliated with the family Methylobacteriaceae and showed high sequence similarities with the genus Microvirga. The strain $\mathrm{BT}^{6} 688^{\top}$ was similar to Microvirga aerilata $5420 \mathrm{~S}-16^{\top}$ (98.5\% of $16 \mathrm{~S}$ rRNA gene similarity) and Microvirga makkahensis SV $1470^{\top}$ ( $98.2 \%$ of $16 \mathrm{~S}$ rRNA gene similarity). These values were around or below the $98.7 \% 16 \mathrm{~S}$ rRNA gene sequence similarity recently used as the threshold for bacterial species classification (Chun et al. 2018). Analysis of neighbor-joining (Fig. 1), maximum-likelihood (Fig. S2), and maximum-parsimony (Fig. S3) trees clearly showed that strain $\mathrm{BT} 688^{\top}$ belongs to the genus Microvirga.

The draft genome length of strain $\mathrm{BT} 688^{\top}$ was $6.62 \mathrm{Mb}(29.6 \times)$ and consisted of 6,356 protein-coding genes and 55 RNA genes including 2 rRNA genes and 53 tRNA genes. The genome sequence of strain BT688 ${ }^{\top}$ was deposited in GenBank under the accession number NZ_JACXAB000000000. The DNA G + C contents of strain $\mathrm{BT} 688^{\top}$ was $62.2 \mathrm{~mol} \%$. which value was within the range of the $\mathrm{G}+\mathrm{C}$ contents of the genus Microvirga (63.5-64.3 mol\%). The average nucleotide identity (ANI) value between strain BT688 ${ }^{\top}$ 
and the most closely related type strain $5420 \mathrm{~S}-16^{\top}$ (genus Microvirga, Microvirga aerilata) was $83.3 \%$. This value is below the ANI species threshold (95-96 \% ANI value) as described by Ritcher and RosselloMora (2009).

The digital DNA-DNA hybridization value between strain BT688 ${ }^{\top}$ and Microvirga aerilata $5420 \mathrm{~S}-16^{\top}$ was $16 \%$, which is below the cutoff (70\%) point (Meier-Kolthoff et al. 2013).

\section{Chemotaxonomic characterization}

The fatty acid profiles of strain $\mathrm{BT} 688^{\top}$ and two reference strains of genus Microvirga were presented in Table 2. The major fatty acid of strain $\mathrm{BT} 688^{\top}$ was $\mathrm{C}_{18: 1} \omega 7 \mathrm{c}(76.0 \%)$. Strain $\mathrm{BT}^{\mathrm{T}} 688^{\top}$ had small amounts of $\mathrm{C}_{19: 0}$ cyclo $\omega 8 c(\mathrm{ND})$ and $\mathrm{C}_{16: 0}(5.8 \%)$, whereas other closely related Microvirga species (M. aerilata 5420S- $16^{\top}$ and $M$. makkahensis SV1470 $\left.{ }^{\top}\right)$ contained larger amounts of corresponding fatty acids $\left(\mathrm{C}_{19: 0}\right.$ cyclo $\omega 8$ c: $1.6 \%$ and $18.8 \%$, respectively; $\mathrm{C}_{16: 0}: 6.3 \%$ and $9.0 \%$, respectively). Strain $\mathrm{BT} 688^{\top}$ contained $\mathrm{C}_{14: 0} 30 \mathrm{H} / \mathrm{C}_{16: 1}$ iso I (2.8 \%) and $\mathrm{C}_{16: 1} \omega 7 c / \mathrm{C}_{16: 1} \omega 6 c(9.6 \%)$, while other closely related Microvirga species ( $M$. aerilata $5420 \mathrm{~S}-16^{\top}$ and $M$. makkahensis $S V 1470^{\top}$ ) did not contain those type of fatty acids.

The polar lipids of strain $\mathrm{BT} 688^{\top}$ consisted of one diphosphatidilglycerol (DPG), one phosphatidylglycerol $(P G)$, one phosphatidylethanolamine (PE), one phosphatidylcholine (PC), one amino lipid (AL), one aminophospholipid (APL), one phospholipid (PL) and two unknown lipids (L) (Fig. S4). The major respiratory quinone of strain $\mathrm{BT}^{\mathrm{T}} 688^{\mathrm{T}}$ was $\mathrm{Q}-10$. The results of the chemotaxonomic analysis indicated that strain $\mathrm{BT} 688^{\mathrm{T}}$ is similar to those of the other species in the genus Microvirga. Based on phenotypic, phylogenetic, and biochemical characteristics, it can be concluded that strain $\mathrm{BT}^{\mathrm{T}} 688^{\top}$ represents a novel species of the genus Microvirga, for which the name Microvirga jeongseonensis is proposed.

\section{Description ofMicrovirga jeongseonensissp. nov.}

Microvirga jeongseonensis (jeong.seon.en'sis. N.L. adj. jeongseonensis from Jeongseon in Korea, where the type strain was isolated).

Cells are Gram-negative, aerobic, rod-shaped, $0.5-1.2 \mu \mathrm{m}$ in diameter and 1.2-2.5 $\mu \mathrm{m}$ in length. Colonies are circular, convex, and light pink colored on Reasoner's 2A (R2A) agar plates after growth for three days at $25^{\circ} \mathrm{C}$. Growth is observed at temperatures ranging from 10 to $30^{\circ} \mathrm{C}$ (optimum $25^{\circ} \mathrm{C}$ ). The pH range for growth is 6.0-9.0 (optimum pH 7.0) on R2A agar. Cells grow on Reasoner's 2A agar (R2A), Luria-Bertani agar (LB), Tryptic Soy Agar (TSA), Nutrient Agar (NA), and Macconkey (MAC) agar (weakly). Cells are positive for oxidase and catalase activity. The major respiratory quinone is Q-10. The dominant cellular fatty acids are $\mathrm{C}_{18: 1} \omega 7 c(76.0 \%)$. The major polar lipids are diphosphatidylglycerol (DPG), phosphatidylglycerol (PG), phosphatidylethanolamine (PE), and phosphatidylcholine (PC). Positive for nitrate reduction to $\mathrm{N}_{2}$ (API 20NE). Positive for esterase (C4) and acid phosphatase (API ZYM). The whole-genome sequence of strain $\mathrm{BT} 688^{\top}$ has been deposited in GenBank under the accession number NZ_JACXAB000000000 (6.62 Mb). The genome-based G + C content is $62.2 \mathrm{~mol} \%$. The GenBank 
accession number for the $16 \mathrm{~S}$ rRNA gene sequence of strain $\mathrm{BT} 688^{\top}$ is $\mathrm{MT795750}$ (1,419 bp). The type strain $\mathrm{BT}^{688^{\top}}\left(=\mathrm{KCTC} X X X X^{\top}=\mathrm{NBRC} 114857^{\top}\right)$ was isolated from a soil sample collected in Jeongseon city $\left(37^{\circ} 22^{\prime} 38.1^{\prime \prime} \mathrm{N} 128^{\circ} 47^{\prime} 17.0^{\prime \prime E}\right)$, South Korea.

\section{Declarations}

The 16S rRNA gene sequence of strain $B T 688^{\top}$ was deposited in GenBank/EMBL/DDBJ under the accession number MT795750. The draft genome sequence of $B T 688^{\top}$ is available with the following accession number NZ_JACXAB000000000.

\section{Acknowledgments}

This work was supported by a research grant from Seoul Women's University (2021) and by a grant from the National Institute of Biological Resources (NIBR), funded by the Ministry of Environment (MOE) of the Republic of Korea (NIBR202002108), and by the National Research Foundation of Korea (NRF) grant funded by the Korea government (MSIT) (No. 2020R1G1A110144).

Conflicts of interest: The authors declare that there are no conflicts of interest.

Ethical Approval: This article does not contain any studies with human participants or animals.

\section{Author Contributions:}

All authors contributed equally to this manuscript.

\section{References}

1. Cappuccino JG, Sherman N (2002) Microbiology- A laboratory manual, 6th edn. Pearson Education, Inc. Benjamin Cummings, California

2. Chun J, Oren A, Ventosa A, Christensen H, Arahal DR et al (2018) Proposed minimal standards for the use of genome data for the taxonomy of prokaryotes. Int J Syst Evol Microbiol 68:461-466. https://doi.org/10.1099/ijsem.0.002516

3. Felsenstein $J(1981)$ Evolutionary trees from DNA sequences: a maximum likelihood approach. $J$ Mol Evol 17:368-376. https://doi.org/10.1007/BF01734359

4. Felsenstein $\mathrm{J}$ (1985) Confidence limit on phylogenies: an approach using the bootstrap. Evolution 39:783-791. https://doi.org/10.1111/j.1558-5646.1985.tb00420.x

5. Fitch WM (1971) Toward defining the course of evolution: minimum change for a specific tree topology. Syst Zool 20:406-416. https://doi.org/10.2307/2412116

6. Hiraishi A, Ueda Y, Ishihara J, Mori T (1996) Comparative lipoquinone analysis of influent sewage and activated sludge by high-performance liquid chromatography and photodiode array detection. $\mathrm{J}$ Gen Appl Microbiol 42:457-469. https://doi.org/10.2323/jgam.42.457 
7. Jimenez-Gomez A, Saati-Santamaria Z, Igual JM, Rivas R, Mateos PF, Garcia-Fraile P (2019) Genome Insights into the Novel Species Microvirga brassicacearum, a Rapeseed Endophyte with Biotechnological Potential. Microorganisms 7:0

8. Kanso S, Patel BK (2003) Microvirga subterranea gen. nov., sp. nov., a moderate thermophile from a deep subsurface Australian thermal aquifer. Int J Syst Evol Microbiol 53:401-406. https://doi.org/10.1099/ijs.0.02348-0

9. Kimura M (1983) The Neutral Theory of Molecular Evolution. Cambridge University Press, Cambridge

10. Komagata K, Suzuki K (1987) 4 Lipid and cell-wall analysis in bacterial systematics. Method Microbiol 19:161-207. https://doi.org/10.1016/S0580-9517(08)70410-0

11. Kumar S, Stecher G, Li M, Knyaz C, Tamura K (2018) MEGA X: Molecular Evolutionary Genetics Analysis across Computing Platforms. Mol Biol Evol 35(6):1547-1549. https://doi.org/10.1093/molbev/msy096

12. Li J, Gao R, Chen Y, Xue D, Han J, Wang J, Dai Q, Lin M, Ke X, Zhang W (2020) Isolation and Identification of Microvirga thermotolerans HR1, a Novel Thermo-Tolerant Bacterium, and Comparative Genomics among Microvirga Species. Microorganisms 8:0

13. Liu ZT, Xian WD, Li MM, Liu L, Ming YZ, Jiao JY, Fang BZ, Xiao M, Li WJ (2020) Microvirga arsenatis sp. nov., an arsenate reduction bacterium isolated from Tibet hot spring sediments. Antonie Van Leeuwenhoek 113:1147-1153. https://doi.org/10.1007/s10482-020-01421-6

14. Meier-Kolthoff JP, Auch AF, Klenk HP, Göker M (2013) Genome sequence-based species delimitation with confidence intervals and improved distance functions. BMC Bioinform 14:60

15. Minnikin DE, O’Donnell AG, Goodfellow M, Alderson G, Athalye M, Schaal A, Parlett JH (1984) An integrated procedure for the extraction of bacterial isoprenoid quinones and polar lipids. $J$ Microbiol Meth 2:233-241. https://doi.org/10.1016/0167-7012(84)90018-6

16. Msaddak A, Rejili M, Duran D, Mars M, Palacios JM, Ruiz-Argueso T, Rey L, Imperial J (2019) Microvirga tunisiensis sp. nov., a root nodule symbiotic bacterium isolated from Lupinus micranthus and L. luteus grown in Northern Tunisia. Syst Appl Microbiol 42:126015. https://doi.org/10.1016/j.syapm.2019.126015

17. Saitou N, Nei M (1987) The neighbor-joining method: a new method for reconstructing phylogenetic trees. Mol Bio Evol 4:406-425. https://doi.org/10.1093/oxfordjournals.molbev.a040454

18. Sasser M (1990) Identification of Bacteria by Gas Chromatography of Cellular Fatty Acids. In: MIDI Technical Note 101. MIDI Inc, Newark

19. Tatusova T, DiCuccio M, Badretdin A et al (2016) NCBI prokaryotic genome annotation pipeline. Nucleic Acids Res 44:6614-6624. https://doi.org/10.1093/nar/gkw569

20. Wang F, Yang L, Deng J, Liu X, Lu Y, Chen W, Wu J (2019) Microvirga calopogonii sp. nov., a novel alphaproteobacterium isolated from a root nodule of Calopogonium mucunoides in Southwest China. Antonie Van Leeuwenhoek 112:1593-1602. https://doi.org/10.1007/s10482-019-01285-5

21. Weisburg WG, Barns SM, Pellerier DA, Lane DJ (1991) 16S ribosomal DNA amplification for phylogenetic study. J Bacteriol 173:697-703. https://doi.org/10.1128/jb.173.2.697-703.1991 
22. Weon HY, Kwon SW, Son JA, Jo EH, Kim SJ, Kim YS, Kim BY, Ka JO (2010) Description of Microvirga aerophila sp. nov. and Microvirga aerilata sp. nov., isolated from air, reclassification of Balneimonas flocculans

23. Yoon S, Ha S, Kwon S, Lim J, Kim Y et al (2017) Introducing EzBioCloud: a taxonomically united database of 16S rRNA gene sequences and whole-genome assemblies. Int J Syst Evol Microbiol 67:1613-1616. https://doi.org/10.1007/s10482-017-0844-4

24. Zhang XJ, Zhang J, Yao Q, Feng GD, Zhu HH (2019) Microvirga flavescens sp. nov., a novel bacterium isolated from forest soil and emended description of the genus Microvirga. Int J Syst Evol Microbiol 69:667-671. https://doi.org/10.1099/ijsem.0.003189

\section{Tables}

Table 1. Different characteristics of Microvirga jeongseonensis and closely related species of genus Microvirga.

Taxa: 1, strain $\mathrm{BT}^{\mathrm{T}} 688^{\top}$ (data was obtained in this study); 2, M. aerilata $5420 \mathrm{~S}-16^{\top}$ (data was taken Weon et al. 2010); 3, M. makkahensis SV1470' (data was taken Veyisoglu et al. 2015

+, positive; -, negative; $w$, weak positive 


\begin{tabular}{|lccc|}
\hline & 1 & 2 & 3 \\
\hline Urease & - & - & + \\
\hline D-Glucose & - & - & + \\
\hline L-Arabinose & - & - & + \\
\hline D-Ribose & W & W & - \\
\hline Acid phosphatase & + & + & - \\
\hline Alkaline phosphatase & - & + & + \\
\hline Lactic acid & + & - & - \\
\hline 3-Hydroxybenzoic acid & - & + & - \\
\hline D-glucose & - & - & + \\
\hline D-sorbitol & - & - & + \\
\hline 4-hydroxybenzoic acid & - & + & - \\
\hline Esterase (C4) & - & + & - \\
\hline Lipase (C14) & - & + & + \\
\hline Trypsin & - & + & + \\
\hline Naphtol-AS-Bl-phosphohydrolase & - & + & + \\
\hline
\end{tabular}

Table 2. Cellular fatty acid profiles of Microvirga jeongseonensis sp. nov., and closely related species of genus Microvirga.

Taxa: 1, strain BT688 ${ }^{\top}$ (this study); 2, M. aerilata $5420 \mathrm{~S}-16^{\top}$ (Weon et al. 2010); 3, M. makkahensis SV1470 (Veyisoglu et al. 2015). All strains were grown on R2A agar at $25-28^{\circ} \mathrm{C}$. ND, not detected; TR, trace amount $(<1 \%)$. 


\begin{tabular}{|c|c|c|c|}
\hline & 1 & 2 & 3 \\
\hline \multicolumn{4}{|l|}{ Saturated } \\
\hline $\mathrm{C}_{14: 0}$ & $\mathrm{TR}$ & TR & 1.9 \\
\hline$C_{16: 0}$ & 5.8 & 6.3 & 9.0 \\
\hline $\mathrm{C}_{18: 0}$ & 2.2 & 8.6 & 4.5 \\
\hline \multicolumn{4}{|l|}{ Unsaturated } \\
\hline $\mathrm{C}_{16: 1} \operatorname{sic} 9$ & ND & 2.5 & 4.8 \\
\hline $\mathrm{C}_{18: 1} \omega 7 c$ & 76.0 & 74.1 & 52.0 \\
\hline \multicolumn{4}{|l|}{ Branched-chain fatty acid } \\
\hline $\mathrm{C}_{18: 1} \omega 7 c 11$-methyl & 1.1 & ND & $N D$ \\
\hline \multicolumn{4}{|l|}{ Hydroxy fatty acids } \\
\hline $\mathrm{C}_{18: 0} 3 \mathrm{OH}$ & $\mathrm{TR}$ & 1.2 & 2.7 \\
\hline \multicolumn{4}{|l|}{ Cyclo } \\
\hline $\mathrm{C}_{17: 0}$ cyclo & ND & ND & 2.8 \\
\hline $\mathrm{C}_{19: 0}$ cyclo $\omega 8 \mathrm{c}$ & ND & 1.6 & 18.8 \\
\hline \multicolumn{4}{|l|}{ Summed feature } \\
\hline $2 ; \mathrm{C}_{14: 0} 3 \mathrm{OH} / \mathrm{C}_{16: 1}$ iso I & 2.8 & ND & ND \\
\hline 3; $\mathrm{C}_{16: 1} \omega 7 c / \mathrm{C}_{16: 1} \omega 6 c$ & 9.6 & ND & ND \\
\hline $4 ; C_{17: 1}$ iso $l / C_{17: 1}$ anteiso $B$ & ND & ND & 1.8 \\
\hline
\end{tabular}

Figures 


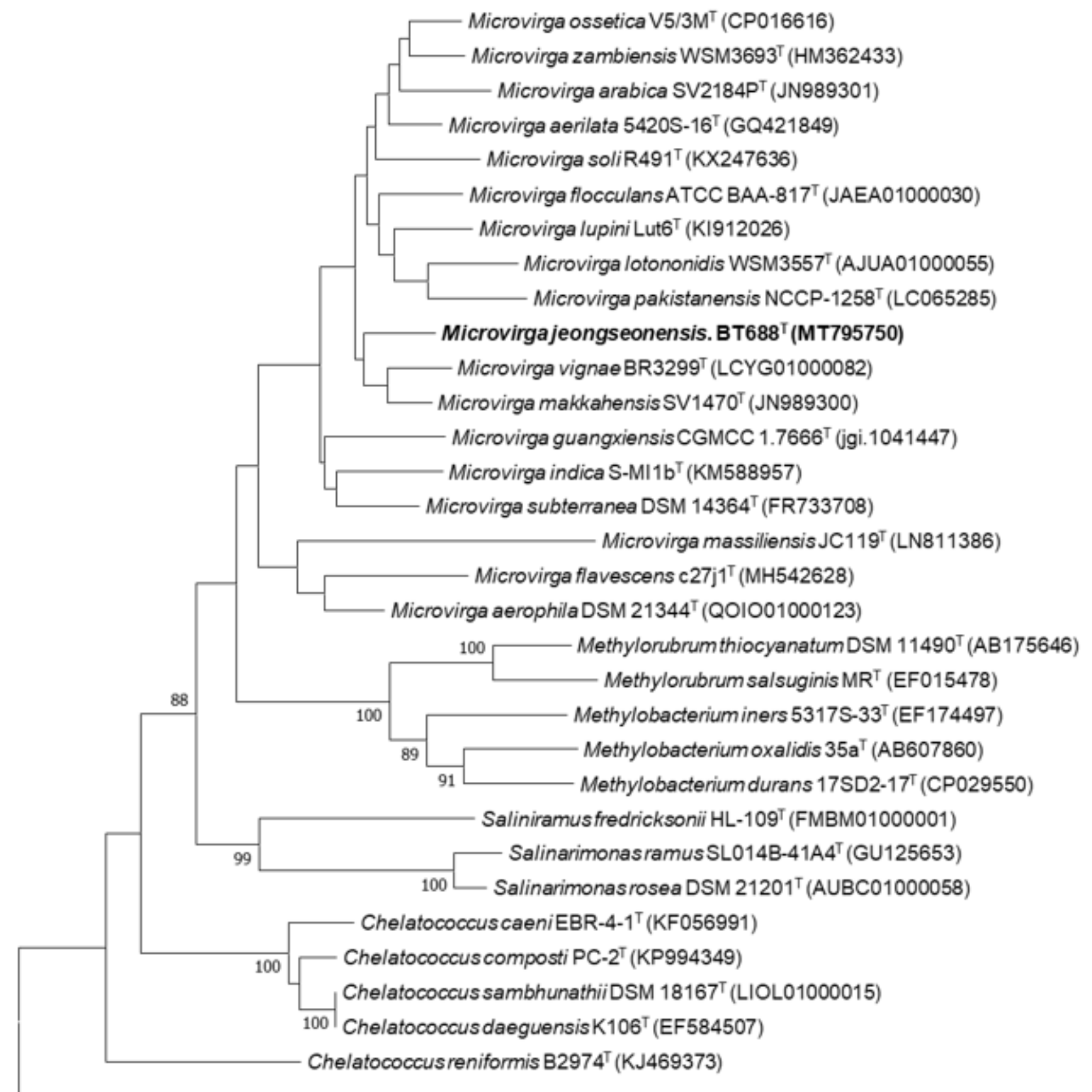

Phyllobacterium loti S658' (NR133818)

\section{Figure 1}

Neighbor-joining phylogenetic tree constructed from a comparative analysis of 16S rRNA gene sequences showing the relationships of strain BT688T with closely related validly published species. Bootstrap values (based on 1,000 replications) greater than $70 \%$ are indicated at the branch nodes. Phyllobacterium loti S658T was used as an outgroup. Bar, 0.01 substitutions per nucleotide position.

\section{Supplementary Files}


This is a list of supplementary files associated with this preprint. Click to download.

- SupplementaryData.docx 